UDC 091(=163.41): 027.54(497.11 Beograd) https://doi.org/10.18485/ms_zmss.2021.100.5

Анатолий Турилов

Институт славяноведения РАН

aaturilov@gmail.com

Anatoly Turilov

Institute of Slavic Studies of the RAS

aaturilov@gmail.com

\title{
ЧТО ЗНАЧАТ СЛОВА «АЗБУЧНЫЕ СТИХИ КОНСТАНТИНА ФИЛОСОФА» В МИНЕЕ ПРАЗДНИЧНОЙ ХІV В. СТАРОГО \\ СОБРАНИЯ НАЦИОНАЛЬНОЙ БИБЛИОТЕКИ СЕРБИИ № 135 (293)? \\ К ВОПРОСУ ОБ АВТОРСТВЕ ДРЕВНЕЙШИХ СЛАВЯНСКИХ АЗБУЧНЫХ СТИХИР
}

\section{WHAT DO THE WORDS "ALPHABET POEMS BY KONSTANTIN THE PHILOSOPHER" MEAN IN THE FOURTEENTH-CENTURY HOLIDAY MINE IN OLD COLLECTION OF THE NATIONAL LIBRARY OF BELGRADE № 135 (293)? THE QUESTION ABOUT THE AUTHORITY OF THE ANCIENT SLAVIC ALPHABETIC VERSE}

Статья посвящена одной из погибших в 1941 г. рукописей Национальной Библиотеки в Белграде, Минее праздничной XIV в., содержавшей, как выясняется из опубликованных в 1952 г. дополнений С. Матича к каталогу Л. Стояновича, ряд уникальных известий. Главное состоит в том, что цикл славянских азбучных стихир в ее составе, относимых исследователями к наследию учеников Кирилла и Мефодия, имел указание на авторство. Этим автором является «Константин Философ», который надежно отождествляется с выдающимся гимнографом Константином Преславским.

Ключевые слова: Национальная библиотека Сербии, погибшая коллекция, Минея праздничная, азбучные стихиры, Константин Философ.

The article focuses on one of the manuscripts of the National Library in Belgrade that that was destroyed in 1941, the fourteenth-century Holiday Mine, which contained a number of unique news, as it turns out from S. Matić's additions to L. Stojanović's catalog published in 1952. The main thing is that the cycle of Slavic alphabetic stichera in its composition, attributed by researchers to the legacy of the disciples of Cyril and Methodius, had an indication of authorship. This author is "Konstantin the Philosopher", who is reliably identified with the outstanding hymnographer Konstantin Preslavsky.

Keywords: National Library of Serbia, lost collection, festive Minea, abc stichera, Konstantin the Philosopher. 
Посвящается Климентине Ивановой, полвека назад впервые введшей их в научный оборот.

Общеизвестно, что потери, понесенные мировой палеославистикой от гибели в 1941 г. рукописного собрания Народной Библиотеки Сербии в результате гитлеровской бомбардировки Белграда (см. об этом, к примеру Богдановић 1974, Дурковић-Јакшић 1984-1985), невосполнимы и в реальности не поддаются учёту. Прежде всего по той причине, что мы недостаточно хорошо представляем себе (с точки зрения как датировки и иллюминации, так и, прежде всего, разумеется, содержания) эту погибшую коллекцию1. Описание основной ее части, старшей по времени поступления в хранилище, составленное Л. Стояновичем (Стојановић 1903), достаточно кратко, за исключением сборников небогослужебного содержания (ср. оценку каталога в послесловии к его репринту - Штављанин- Ђорђевић 1982). В значительной мере (но не целиком²) эту традицию продолжает и основная часть описания С. Матича, посвященного поступлениям рукописей между 1903 и 1941 г. и составленного еще до трагического события, но опубликованного лишь в 1952 г. (Матић 1952: 1-231).

Представляется, что давно назрела необходимость максимально полной реконструкции погибшего собрания на основе данных литературы и неопубликованных источников (как письменных, так и изобразительных), сохранившихся в архивах исследователей, работавших с рукописями НБС до трагедии 1941 г., причем, разумеется, не только югославских, но и зарубежных (прежде всего австро-венгерских, болгарских, немецких, российских и чешских). Мысль эта давно высказывалась в югославской научной литературе (Радојчић 1954; Богдановић 1974), но до ее реализации дело до сих пор так и не дошло 3 . Ближе всех к решению проблемы подошел академик Д. Богданович, включивший сведения о кодексах старого собрания НБС (в числе других рукописей, погибших либо рассеянных во время Второй Мировой войны) в Инвентарь кириллических рукописей XI-XVII вв. в Югославии (Богдановић 1982: 191-222).

1 Особенно это ясно сейчас, когда в результате открытий и исследований последнего сорокалетия (середина 1970-х — середина 2000-х гг.) в научный оборот введен без преувеличения огромный (свыше 100 памятников) корпус древнейших славянских гимнографических текстов, созданных учениками Кирилла и Мефодия (см. об этом, например, Нововыявленные оригинальные произведения 2003, Попов 2003а, Попов 2003б, Станчев 2003, Мошкова, Турилов 2006, Йовчева 2008), поскольку большую часть погибших рукописей, естественно, составляли богослужебные книги.

2 О принципах описаниях в каталоге см.(Матић 1952: V-VII). Немаловажные дополнения и уточнения к каталогу Л. Стояновича содержит также публикация М. Н. Сперанского, не получившая известности в сербской исследовательской литературе (Сперанский 1914-1915; Турилов 2018: 11-20).

3 Несколько лет назад автор этих строк совместно с сотрудницей ОР РНБ Ж. Л. Левшиной выступили с инициативой составления свода сведений о рукописях старого собрания НБС, сохранившихся в архивах российских славистов (и прежде всего П. А. Лаврова, М. Н. Сперанского и А. И. Яцимирского, много работавших в Белграде). Наше предложение не встретило, однако, понимания со стороны тогдашнего руководства НБС. 
Можно не сомневаться, что в случае реализации этого проекта исследователей ожидает немало находок и открытий разного уровня и значения. Проиллюстрирую это одним достаточно выразительным, на мой взгляд, примером.

«Опис» рукописей НБС, составленная С. Матичем, о которой уже шла речь выше, содержит, помимо описания кодексов, поступивших в собрание в 1903-1941 гг., немаловажные дополнения, уточнения и исправления к предшествующему каталогу Л. Стояновича (Матић 1952: 233-271); можно лишь выразить сожаление, что при переиздании последнего эта часть книги Матича не была репринтирована в приложении к нему) 4 .

Большинство их относится к записям, не упомянутым и не воспроизведенным у Стояновича (в том числе писцовым), и к славянским памятям в месяцесловах, в целом ряде случаев (Матић 1952: 239-241, № 135 (223), 142 (663); 243-244, № 186 (607), 198 (676), 200 (671); 245-246, № 209 (15), 215 (679), 245 (715), 248 (711); 248-249, № 277 (720), 291 (721); 250, №307 (733), 309 (494), 317 (262); 254, №390 (27); 258-262, №469 (33); 265-266, № 550 (179), 581 (743)) речь идет о существенном уточнении и дополнении содержания. На фоне всего этого особенно выделяется № 293 (135 по каталогу), описанный у Стояновича как Минея общая первой половины XIV в. (Стојановић 1903: 45-46), полученная из Скопле. С. Матич сообщает (Матић 1952: 239 241), что на деле речь идет о Минее праздничной 5 и приводит пространную запись писца (иеромонаха Иоанна) на обороте первого листа, не отмеченную (а, вероятно, и не замеченную) Стояновичем ${ }^{6}$ и представляющую отдельное небольшое литературное произведение (в наборе занимает почти целую страницу (Матић 1952: 240-241).

К сожалению, С. Матич не дал постатейной росписи кодекса, которой, как будет показано ниже, тот несомненно заслуживал. Тем не менее, даже сообщенная описателем информация достойна самого пристального внимания. Достаточно упомянуть здесь помещенную на л. 122 под 8 мая память «первого Арсения, архиепископа Болгарского» (Матић 1952: 240), представляющей для исследователей несомненную историко-культурную загадку (Турилов, Јелесијевић 2020: 262. Примеч. 28).

Однако еще больший сюрприз представляет не вполне ясное упоминание в описании наличие в рукописи «азбучных стихов презвитера Кон-

4 Дополнения к каталогам вообще плохо читаются большинством исследователей, обычно разыскивающих в справочниках сугубо конкретную информацию, а в данном случае речь идет о дополнениях к чужому каталогу. Говорю об этом с полным знанием дела, поскольку неоднократно получал (и получаю вплоть до настоящего времени) от коллег вопросы по поводу датировки рукописей, при том, что большинство этих сведения было опубликовано еще в 2002 г. в приложении к вып. 1 Сводного каталога XIV в. (CK XIV 2002: 559-591), а значительная часть даже раньше (Турилов 2000).

5 Исправления Матича учтены Д. Богдановичем в его Инвентаре (Богдановић 1982: 205, R 357). О причинах смешения этих типов книг (точнее, замены названия «Праздничная Минея» на «общая») в научной и научно-справочной литературе см.: (Турилов 2016).

6 Она не включена исследователем в состав изданного им свода записей и надпи-

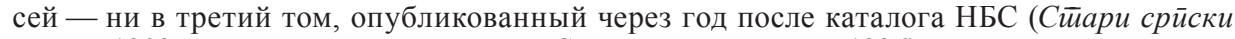
зайиси 1903, ни в дополнительный том Сӣари срйски зайиси 1926). 
стантина, означенного здесь как «Константина Философа»»» (Матић 1952: 239). Следует согласиться с описателем в отношении этой атрибуции ${ }^{7}$, поскольку светское имя славянского первоучителя, совпадающее с именем его ученика, в отличие от монашеского (Кирилл) ${ }^{8}$, встречается в славянской письменной традиции крайне редко — в сущности, такое надписание сопровождает только ряд списков так называемой Азбучной молитвы или «Прогласа», стихотворного предисловия к Учительному Евангелию Константина Преславского (Куев 1985: 50).

Но если авторство Константина Преславского применительно к азбучному песнопению/песнопениям в составе погибшей Праздничной Минеи НБС не вызывает особых сомнений, то этого нельзя сказать о жанре произведения («азбучные стихи»), поскольку таковым абсолютно не место в данном типе богослужебной книги, включающей службы (и, в ряде случаев, отдельные песнопения), расположенные в порядке месяцеслова. По всей вероятности, в текст С. Матича вкралась ошибка прочтения или опечатка и речь идет здесь здесь не о «стихах» а о стихирах. Она вполне возможна, учитывая особенности сокращенного написания слов «стихира / стихиры» в славянских богослужебных рукописях как «стиХ» с выносным $\mathrm{X}^{9}$.

Циклы славянских азбучных стихир с глаголической последовательностью букв на Рождество Христово и Богоявление были впервые введены в научный оборот болгарской исследовательницей Климентиной Ивановой (Ивановой-Константиновой), юбилей которой мы отмечали в этом году, 50 лет назад и опубликованы ею по двум южнославянским (болгарскому и сербскому) спискам (Иванова-Константинова 1971). Позднее Б. Йованович-Стипчевич были найдены и изданы два других цикла славянских азбучных стихир по неполному сербскому списку XIII в. (Јовановић-Стипчевић 1982). В докладе на съезде славистов в Любляне Г. Попов на основании новых находок говорит уже о целой традиции этих циклов в болгарских, русских и сербских Минеях, праздничных и служебных, начиная с XII в. (Попов 2003a: 32-47). Однако ни в одной из этих рукописей, в отличие от погибшего списка НБС, имя Константина Философа не зафиксировано, в этом смысле данная Минея уникальна и позволяет надежно причислять

7 В предшествующей публикации (Турилов 2018: 133-134), где эта атрибуция рассматривалась попутно, я принимал отождествление С. Матича, не рассматривая вопрос его достоверности, но сейчас, по-прежнему соглашаясь с сербским исследователем, считаю необходимым разобраться с могущими возникнуть сомнениями и недоразумениями (см. ниже).

8 С этим именем и прозвищем в заглавии в рукописной традиции встречаются и сочинения Константина Преславского (Куев 1985: 50; Турилов 1985) и (вероятно из-за общего прозвища) сравнительно недавно (в конце 1970-х гг.) открытого киевского автора ХІ в. Григория Философа (Соболевский 1901; Рыков, Турилов 1981; Турилов 2006). В то же время целый ряд памятников с именем Кирилла Философа в заголовке (Сухомлинов 1855) остается не атрибутированным и нет надежды, что это случится в будущем. Преимущественно это учительные слова с явно апокрифическими элементами в содержании.

9 См., например, новгородскую Минею служебную ХІІ в. (Москва, ГИМ, Синодальное собрание, № 162) на декабрь, л. 176 и др. (Gottesdienstmenaum 2000: 352). 
эти циклы к и без того богатому творческому наследию Константина Преславского. К сожалению, краткость сведений, приводимых С. Матичем, не позволяет связать это указание на авторство с конкретным циклом (о вариантах расположения их в рукописях — Попов 2003a: 33) и даже о календарной приуроченности «азбучных стихов». Но допустимо предположение, что речь идет об остатке заглавия комплекса, включавшего (во всяком случае, первоначально) все 4 цикла комплекса алфавитных стихир.

\section{ЛИТЕРАТУРА}

Богдановић Димитрије. „Стара српска рукописна књига и проблем реконструкције њених

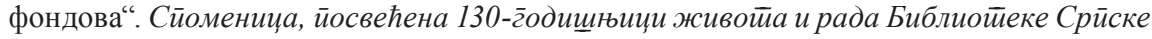
Академије наука и уметиносӣu. Посебна издања САНУ. Београд, 1974. Књ. 476 (Споменица. Књ. 65): 37-42.

Богдановић Димитрије. „Стара српска рукописна књига и проблем реконструкције њених

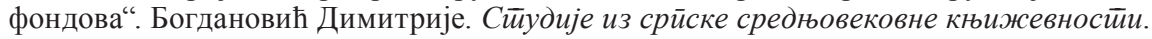
Београд, 1997: 80-88.

Богдановић Димитрије. Инвент̄ар ћирилских рукойиса у Југ̄ославији (XI - XVII в.). Београд, 1982.

Дурковић-Јакшић Љубомир. „О пропасти Народне Библиотеке у Београду 1941. и судбини њених реткости“. Археогррафски йрилози 6-7 (1984-1985): 7-50.

Иванова-Константинова Климентина. „Два неизвестни азбучни акростиха с глаголическа подредба на буквите“. Константин Кирил Философ: Доклади от симпозиума, посветен на 1100-годишнината от смъртта му. София, 1971: 341-365.

Йовчева Мария. „Старобългарска химнография“. История на българската средновековна литература. Съставител Анисава Милтенова. София, 2008: 102-123.

Јовановић- Стипчевић Биљана. „Текстолошка установленост састава и броја слова старословенске азбуке према Сӣихирима на Рођење и Кршйеље у срйском ирейису“. Археографски иррилози 3 (1982): 93-122.

Куев Куйо. „Азбучна молитва“. Кирило-Методиевска енциклопедия. Т. 1. София, 1985: $50-54$.

Матић Светозар. Ойис рукойиса Народне Библиоиекке. Са йрилог̄oм: „Породични архив Ращкковића“. Описао др. Мита Костић (Посебна издања САНУ. Књ. 191). Београд, 1952.

Мошкова Людмила, Турилов Анатолий. «Гимнография древнейшая славянская оригинальная““. Православная энщиклопедия. Т. 11 (Георгий - Гомар). Москва, 2006: 495-497, 507.

«Нововыявленные оригинальные произведения древнеславянской гимнографии IX-X вв.». La poesia liturgica slava antica. XIII congresso Internationale degli Slavisti. Blocco tematico 14. Relationi / Древнеславянская литургическая поэзия. ХІІІ Международный съезд славистов (Любляна, 15-21 августа 2003). Тематический блок № 14. Доклады. Roma; Sofia, 2003. Прилож.: 109-112.

Попов Георги. «Новооткрити химнографски произведения на Климент Охридски и Константин Преславски». Български език 1 (1982): 3-36.

Попов Георги. «Акростих в гимнографическом творчестве учеников Кирилла и Мефодия». La poesia liturgica slava antica. XIII congresso Internationale degli Slavisti. Blocco tematico 14. Relationi. Roma; Sofia, 2003a: 30-55.

Попов Георги. «Химнография старобългарска». Кирило-Методиевска енциклопедия. Т. 4. София, 2003б: 400-414.

Радојчић Никола. „Реконструкција збирке рукописа Народне библиотеке у Београду“. Предавање, одржано 24 јуна 1953 у Народној библиотеци у Београду. Библиойекар 2 (1954): 65-71.

Рыков Юрий, Турилов Анатолий. «Из истории русско-болгарских культурных связей XI в. (Григорий Философ - малоизвестный писатель Киевской Руси) ». Русско-болгар- 
ские связи в области книжного дела. Сб. материалов VII болгаро-советского семинара. Москва, 1981: 64-105.

Сводный каталог славяно-русских рукописных книг, хранящихся в России, странах СНГ и Балтии. XIV в. Вып. 1. Отв. ред. Анатолий Турилов. Москва, 2002.

Соболевский Алексей. «Шестоднев Кирилла Философа». Известия ОРЯС. Т. 6. Санкт-Петербург, 1901: 177-202.

Сперанский Михаил. «Белградские рукописи». Библиографическая летопись. Вып. 1. Петроград, 1914: 51-59; Вып. 2. Петроград 1915: 3-20.

Станчев Красимир. «Литургическая поэзия в древнеславянском литературном пространстве (История вопроса и некоторые проблемы изучения)». La poesia liturgica slava antica. XIII congresso Internationale degli Slavisti. Blocco tematico 14. Relationi / Древнеславянская литургическая поэзия. ХІІІ Международный съезд славистов (Любляна, 15-21 августа 2003). Тематический блок № 14. Доклады. Roma; Sofia, 2003: 6-22.

Сйари срйски зайиси и наййиси. Скупио их и средио Љубомир Стојановић. Београд, 1905 (репринт - 1984). Књ. 3.

Се̄ари срйски зайиси и наййиси. Скупио их и средио Љубомир Стојановић. Сремски Карловци, 1926 (репринт - Београд, 1988). Књ. 6.

Стојановић Љубомир. Кайалог̄ Народне Библиойеке у Беог̄раду. IV. Рукописи и старе штампане књиге. Београд, 1903 (репринт - 1982).

Сухомлинов Михаил. «О псевдонимах в древней русской словесности». Известия АH по РЯС 4/3 (1855): стб. 117-159.

Турилов Анатолий. «К истории великоморавского наследия в литературе южных и восточных славян (Слово “о похвале Богородице Кирилла Философа” в рукописной традиции XV-XVII вв.) ». Великая Моравия и ее историческое и культурное значение. Москва, 1985: 253-269 (переиздано с исправлениями, дополнениями и публикацией памятника: Турилов Анатолий. 355. Slavia Cyrillomethodiana: Источниковедение истории и культуры южных славян и Древней Руси. Межславянские культурные связи эпохи средневековья. Москва, 2010: 12-44; Турилов Анатолий. Межславянские связи эпохи Средневековья и источниковедение истории и культуры славян: Этюды и характеристики. Москва: «Знак», 2012: 21-46).

Турилов Анатолий. «Сводный каталог славяно-русских рукописных книг XI-XIII вв., хранящихся в СССР. Ч. 1. Исправления и уточнения». Annali dell' Istituto universario Orientale di Napoli (AION). Slavistica. 1997-1998. Vol. 5. Napoli, 2000: 469-504.

Турилов Анатолий. «Григорий Философ». Православная энциклопедия. Т. 13 (Григорий Палама — Даниэль Ропс). Москва 2005: 71-74.

Турилов Анатолий. «К истории бытования и изучения древнеболгарских рукописей в России первой половины - середины XIX в.: реконструированная Минея праздничная (РНБ, Ф. п. І. 72 + БРАН, 24.4.11) “Палаузовская" или же “Априловская”?». Vis et sapientia: Studia in honorem Anisavae Miltenova. Нови извори, интерпретации и подходи в медиевистиката. София, 2016: 182-189.

Турилов Анатолий. «Климент Охридский и древнейший этап славянской гимнографии». San Clemente di Ocrida: Allievo e maestro / Nell' undicessimo centario del beato transito (916-2016). (Accademia Ambrosiana. Classe di Slavistica, Vol. 7). Milano, 2017: 123-144.

Турилов Анатолий. «“Потерявшиеся” публикации 1914-1915 гг. русских исследователей о средневековых сербских рукописях». Срйско-руске књижевне и кулйурне везе. Ейоха модерна/Сербско-русские литературные и культурные связи. Эпоха модерна. Отв. ред. Корнелия Ичин. Нови Сад; Москва, 2018: 9-32.

Турилов Анатолиј, Јелесијевић Снежана. „Нове чињеница о Светом архиепископу српском Арсенију“. Осам векова ауйокефалије Срйске иравославне иркве. Т. 2. Београд, 2020: 259-276.

Штављанин-Ђорђевић Љубица. „Поговор“. Стојановић Љубомир. Кайалог̄ Народне Библиойеке у Беог̄раду. IV. Рукописи и старе штампане књиге. Репринт. Београд, 1982: 1-23 2-го счета.

Gottesdienstmenaum fur den Monat Dezember. Wiesbaden, 2000. Teil 5: Facsimile der Handschrift Sin. 162. 


\section{REFERENCES}

Bogdanović Dimitrije. „Stara srpska rukopisna knjiga i problem rekonstrukcije njenih fondova“. Spomenica, posvećena 130-godišnjici života i rada Biblioteke Srpske Akademije nauka i umetnosti. Posebna izdanja SANU. Beograd, 1974. Knj. 476 (Spomenica. Knj. 65): 37-42.

Bogdanović Dimitrije. „Stara srpska rukopisna knjiga i problem rekonstrukcije njenih fondova“. Bogdanović Dimitrije. Studije iz srpske srednjovekovne književnosti. Beograd, 1997: 80-88.

Bogdanović Dimitrije. Inventar ćirilskih rukopisa u Jugoslaviji (XI-XVII v.). Beograd, 1982.

Durković-Jakšić Ljubomir. „O propasti Narodne Biblioteke u Beogradu 1941. i sudbini njenih retkosti“. Arheografski prilozi 6-7 (1984-1985): 7-50.

Gottesdienstmenaum fur den Monat Dezember. Wiesbaden, 2000. Teil 5: Facsimile der Handschrift Sin. 162.

Ivanova-Konstantinova Klimentina. „Dva neizvestni azbuchni akrostiha s glagolicheska podredba na bukvite“. Konstantin Kiril Filosof: Dokladi ot simpoziuma, posveten na 1100-godishninata ot sm"rtta mu. Sofiya, 1971: 341-365.

Jovcheva Mariya. „Starob”lgarska himnografiya“. Istoriya na b«lgarskata srednovekovna literatura. S"stavitel Anisava Miltenova. Sofiya, 2008: 102-123.

Jovanović-Stipčević Biljana. „Tekstološka ustanovljenost sastava i broja slova staroslovenske azbuke prema Stihirima na Rođenje i Krštenje u srpskom prepisu“. Arheografski prilozi 3 (1982): 93-122.

Kuev Kujo. „Azbuchna molitva“. Kirilo-Metodievska enciklopediya. T. 1. Sofiya, 1985: 50-54.

Matić Svetozar. Opis rukopisa Narodne Biblioteke. Sa prilogom: „Porodični arhiv Raškovića“. Opisao dr. Mita Kostić (Posebna izdanja SANU. Књ. 191). Beograd, 1952.

Moshkova Lyudmila, Turilov Anatolij. «Gimnografiya drevnejshaya slavyanskaya original'naya». Pravoslavnaya enciklopediya. T. 11 (Georgij — Gomar). Moskva, 2006: 495-497, 507.

«Novovyyavlennye original'nye proizvedeniya drevneslavyanskoj gimnografii IX-X vv.». La poesia liturgica slava antica. XIII congresso Internationale degli Slavisti. Blocco tematico 14. Relationi / Drevneslavyanskaya liturgicheskaya poeziya. XIII Mezhdunarodnyj s«ezd slavistov (Lyublyana, 15-21 avgusta 2003). Tematicheskij blok № 14. Doklady. Roma; Sofia, 2003. Prilozh.: 109-112.

Popov Georgi. «Novootkriti himnografski proizvedeniya na Kliment Ohridski i Konstantin Preslavski». B"lgarski ezik 1 (1982): 3-36.

Popov Georgi. «Akrostih v gimnograficheskom tvorchestve uchenikov Kirilla i Mefodiya». La poesia liturgica slava antica. XIII congresso Internationale degli Slavisti. Blocco tematico 14. Relationi. Roma; Sofia, 2003a: 30-55.

Popov Georgi. «Himnografiya starob"lgarska». Kirilo-Metodievska enciklopediya. T. 4. Sofiya, 2003b: 400-414.

Radojčić Nikola. „Rekonstrukcija zbirke rukopisa Narodne biblioteke u Beogradu“. Predavanje, održano 24. juna 1953. u Narodnoj biblioteci u Beogradu. Bibliotekar 2 (1954): 65-71.

Rykov Yurij, Turilov Anatolij. «Iz istorii russko-bolgarskih kul'turnyh svyazej XI v. (Grigorij Filosof - maloizvestnyj pisatel' Kievskoj Rusi)». Russko-bolgarskie svyazi v oblasti knizhnogo dela. Sb. materialov VII bolgaro-sovetskogo seminara. Moskva, 1981: 64-105.

Svodnyj katalog slavyano-russkih rukopisnyh knig, hranyashchihsya v Rossii, stranah SNG i Baltii. XIV v. Vyp. 1. Otv. red. Anatolij Turilov. Moskva, 2002.

Sobolevskij Aleksej. «Shestodnev Kirilla Filosofa». Izvestiya ORYAS. T. 6. Sankt-Peterburg, 1901: 177-202.

Speranskij Mihail. «Belgradskie rukopisi». Bibliograficheskaya letopis'. Vyp. 1. Petrograd, 1914: 51-59; Vyp. 2. Petrograd 1915: 3-20.

Stanchev Krasimir. «Liturgicheskaya poeziya v drevneslavyanskom literaturnom prostranstve (Istoriya voprosa i nekotorye problemy izucheniya)». La poesia liturgica slava antica. XIII congresso Internationale degli Slavisti. Blocco tematico 14. Relationi / Drevneslavyanskaya liturgicheskaya poeziya. XIII Mezhdunarodnyj s«ezd slavistov (Lyublyana, 15-21 avgusta 2003). Tematicheskij blok № 14. Doklady. Roma; Sofia, 2003: 6-22.

Stari srpski zapisi i natpisi. Skupio ih i sredio Ljubomir Stojanović. Beograd, 1905 (reprint — 1984). Књ. 3.

Stari srpski zapisi i natpisi. Skupio ih i sredio Ljubomir Stojanović. Sremski Karlovci, 1926 (reprint - Beograd, 1988). Knj. 6. 
Stojanović Ljubomir. Katalog Narodne Biblioteke u Beogradu. IV. Rukopisi i stare štampane knjige. Beograd, 1903 (reprint — 1982).

Suhomlinov Mihail. «O psevdonimah v drevnej russkoj slovesnosti». Izvestiya AN po RYAS 4/3 (1855): stb. 117-159.

Štavljanin-Đorđević Ljubica. „Pogovor“. Stojanović Ljubomir. Katalog Narodne Biblioteke u Beogradu. IV. Rukopisi i stare štampane knjige. Reprint. Beograd, 1982: 1-23 2-go scheta.

Turilov Anatolij. «K istorii velikomoravskogo naslediya v literature yuzhnyh i vostochnyh slavyan (Slovo "o pohvale Bogorodice Kirilla Filosofa" v rukopisnoj tradicii XV-XVII vv.) ». Velikaya Moraviya i ee istoricheskoe i kul'turnoe znachenie. Moskva, 1985: 253-269 (pereizdano s ispravleniyami, dopolneniyami i publikaciej pamyatnika: Turilov Anatolij. 355. Slavia Cyrillomethodiana: Istochnikovedenie istorii i kul'tury yuzhnyh slavyan i Drevnej Rusi. Mezhslavyanskie kul'turnye svyazi epohi srednevekov'ya. Moskva, 2010: 12-44; Turilov Anatolij. Mezhslavyanskie svyazi epohi Srednevekov'ya i istochnikovedenie istorii i kul'tury slavyan: Etyudy i harakteristiki. Moskva: «Znak», 2012: 21-46).

Turilov Anatolij. «Svodnyj katalog slavyano-russkih rukopisnyh knig XI - XIII vv., hranyashchihsya v SSSR. CH. 1. Ispravleniya i utochneniya». Annali dell' Istituto universario Orientale di Napoli (AION). Slavistica. 1997-1998. Vol. 5. Napoli, 2000: 469-504.

Turilov Anatolij. «Grigorij Filosof». Pravoslavnaya enciklopediya. T. 13 (Grigorij Palama Daniel' Rops). Moskva 2005: 71-74.

Turilov Anatolij. «K istorii bytovaniya i izucheniya drevnebolgarskih rukopisej v Rossii pervoj poloviny - serediny XIX v.: rekonstruirovannaya Mineya prazdnichnaya (RNB, F. p. I. 72 + BRAN, 24.4.11) "Palauzovskaya" ili zhe "Aprilovskaya"?». Vis et sapientia: Studia in honorem Anisavae Miltenova. Novi izvori, interpretacii i podhodi v medievistikata. Sofiya, 2016: 182-189.

Turilov Anatolij. «Kliment Ohridskij i drevnejshij etap slavyanskoj gimnografii». San Clemente di Ocrida: Allievo e maestro / Nell' undicessimo centario del beato transito (916-2016). (Accademia Ambrosiana. Classe di Slavistica, Vol. 7). Milano, 2017: 123-144.

Turilov Anatolij. «"Poteryavshiesya” publikacii 1914-1915 gg. russkih issledovatelej o srednevekovyh serbskih rukopisyah». Srpsko-ruske književne i kulturne veze. Epoha moderne I Serbsko-russkie literaturnye i kul'turnye svyazi. Epoha moderna. Otv. red. Kornelija Ičin. Novi Sad; Moskva, 2018: 9-32.

Turilov Anatolij, Jelesijević Snežana. „Nove činjenica o Svetom arhiepiskopu srpskom Arseniju“. Osam vekova autokefalije Srpske pravoslavne crkve. T. 2. Beograd, 2020: 259-276.

Анатолиј Турилов

ШТА ЗНАЧЕ РЕЧИ „АЗБУЧНЕ ПЕСМЕ КОНСТАНТИНА ФИЛОЗОФА“ У ПРАЗНИЧНОМ МИНЕЈУ ХІV В. ИЗ СТАРЕ ЗБИРКЕ НАРОДНЕ БИБЛИОТЕКЕ СРБИЈЕ БР. 135 (293)? ПИТАЮЕ АУТОРСТВА НАЈСТАРИЈИХ СЛОВЕНСКИХ АЗБУЧНИХ СТИХИРА

\section{Резиме}

Чланак је посвећен једном од рукописа Народне библиотеке у Београду уништеног 1941. године - празничном Минеју из XIV в., који садржи низ јединствених новости, како се може видети из додатка С. Матића, штаманог уз каталог Љ. Стојановића. Главна ствар је у томе да циклус азбучних стихира, које се налазе у саставу рукописа и које су биле повезиване с наслеђем ученика Кирила и Методија, садрже позивање на ауторство. Аутор је „Константин Филозоф“ који се убедљиво идентификује са знаменитим химнографом Константином Преславским.

Кључен речи: Народна библиотека Србије, уништена збирка, празнични Минеј, азбучне стихире, Константин Филозоф. 